\title{
Adherence of Haemophilus influenzae to Monkey Respiratory Tissue in Organ Culture
}

\author{
By MARILYN ROBERTS, ${ }^{1,3 *}$ RICHARD F. JACOBS, ${ }^{1,3} \dagger$ JOEL E. HAAS ${ }^{1,4}$ \\ AND ARNOLD L. SMITH ${ }^{1,2,3}$ \\ ${ }^{1}$ Department of Pediatrics and ${ }^{2}$ Regional Primate Research Center, University of Washington, \\ Seattle, WA 98195, USA \\ ${ }^{3}$ Division of Infectious Disease and ${ }^{4}$ Pathology, Children's Orthopedic Hospital and Medical \\ Center, Seattle, WA 98195, USA
}

(Received 4 November 1983; revised 9 January 1984)

\begin{abstract}
We studied the adherence of Haemophilus influenzae to monkey respiratory mucosa using nasal turbinates maintained in organ culture. Adherence of capsulated and rough strains was not inhibited by monosaccharides, sucrose, human albumin, foetal calf serum or polyribophosphate. However, antisera directed against surface components decreased bacterial adherence. Although variation in adherence capacity in individual strains was observed there was no correlation with capsulation, anatomical site of strain isolation or biotype. Bacterial surface structures other than capsular material appear important in effecting upper respiratory tract colonization.
\end{abstract}

\section{INTRODUCTION}

In 1908 Guyot reported studies on the adhesiveness of bacteria, yet the potential importance of this phenomenon was not recognized. The role and mechanism of adherence and its relationship to colonization and pathogenicity was stimulated by the reports of Gibbons \& Van Houte (1971). They described a correlation between the ability of Streptococcus species to adhere to specific oral epithelial cells in vitro and their natural distribution on oral surfaces in vivo. Since then a number of studies on the adherence properties of a variety of bacteria has been described (Beachey, 1981; Craven et al., 1980; Johansen et al., 1979; McGee et al., 1981; Reed \& Williams, 1978; Salit \& Morton, 1981). However, little is known about the role of adherence in Haemophilus influenzae infections. Recently, Lampe et al. (1982) compared the adhesive capacity of capsulated and unencapsulated strains isolated from patients. They found the majority of capsulated $H$. influenzae to adhere poorly to human buccal epithelial cells, while 75$90 \%$ of unrelated unencapsulated strains adhered in greater numbers to these cells.

Adherence may reflect the ability of the strain to colonize animal tissue. Moxon \& Vaughn (1981) compared the ability of isogenic pairs of $H$. influenzae (the capsulated transformants and the unencapsulated parent) to colonize the infant rat. In contrast with the adherence data of Lampe, they found no relationship between possession of a capsule and the ability to colonize the nasopharynx. However, the capsulated transformants were recovered from the nasopharynx for $14 \mathrm{~d}$ longer than the unencapsulated parent.

The disparity between the duration of colonization in vivo and adherence capacity in vitro may be due to inherent differences between the model systems (buccal epithelial cells versus nasopharyngeal mucosa) or could indicate a lack of correlation between adherence capacity and

† Present address: Arkansas Children's Hospital, 804 Wolfe Avenue, Little Rock, Arkansas 72201, USA.

Abbreviations: BHI, brain/heart infusion broth; PBSG, phosphate-buffered saline $+0.1 \%$ gelatin; PRP, polyribophosphate. 
colonization by $H$. influenzae. In an attempt to distinguish between these possibilities, we examined adherence using organ cultures derived from the upper respiratory tract of monkeys. This system has the advantage of using viable intact respiratory tissue.

In this paper we report on the characteristics of the respiratory organ culture model and examine the adherence patterns of certain capsulated and unencapsulated strains of $H$. influenzae.

\section{METHODS}

Bacteria. The $H$. influenzae strains studied are described in Table 2.

Media. The medium used to grow $H$. influenzae consisted of supplemented brain/heart infusion broth $(3.5 \%$, w/v; BHI) and GC medium base agar plates (Difco) supplemented with $\left(\mathrm{ml}^{-1}\right): 4.0 \mathrm{mg}$ glucose; $50.0 \mu \mathrm{g}$ glutamine $; 5.0 \mu \mathrm{g}$ ferric nitrate $; 0.01 \mu \mathrm{g}$ thiamin pyrophosphate $; 20.0 \mu \mathrm{g} \mathrm{L}$-histidine $; 20.0 \mu \mathrm{g}$ haemin; and $20.0 \mu \mathrm{g}$ $\beta$-nicotinamide adenine dinucleotide (Roberts et al., 1981). Medium 199 (Grand Island Biological Co., Grand Island, NY, USA) containing $10 \%$ (v/v) foetal calf serum and $2 \mathrm{mM}$-L-glutamine (M199), and M199 supplemented with $60 \mu \mathrm{g}$ penicillin $\mathrm{G}$ and $100 \mu \mathrm{g}$ streptomycin $\mathrm{ml}^{-1}$ were used for organ cultures.

Organ cultures. Infant (0-5d) and adult (1-12 years) Macacca nemestrina ware obtained from the Regional Primate Research Center at the University of Washington. Nasal turbinates were removed from the noses of the monkeys immediately after they were killed as part of the Regional Primate Research Center Tissue Program. The tissue was placed in M199 and transported to the laboratory. Nasal turbinates from infant monkeys were cut in half yielding tissue blocks approximately 3 by $1 \mathrm{~mm}(16.0 \pm 2.0 \mathrm{mg}$, sD). Nasal turbinates from adult monkeys were cut into $3 \mathrm{~mm}$ squares $(90 \pm 20 \mathrm{mg}, \mathrm{sD})$ as determined in four different experiments. All tissue was placed in 24-well, flat bottomed tissue trays (Flow Laboratories) with a capacity of $3.5 \mathrm{ml}$. Surface area of the tissue blocks was determined by placing the tissue on a sterile, etched grid slide and measuring the perimeter microscopically.

Attachment studies. The $H$. influenzae strains were grown to late exponential phase in BHI broth and frozen $\left(-70^{\circ} \mathrm{C}\right)$ in $16 \%(\mathrm{v} / \mathrm{v})$ glycerol in BHI broth. On the day of use, samples were thawed and added to BHI, grown to an optical density of 0.7 at $675 \mathrm{~nm}$ and washed in $25 \mathrm{ml}$ phosphate-buffered saline $(7.5 \mathrm{~g} \mathrm{NaCl}, 0.2 \mathrm{~g} \mathrm{KCl}, 0.2 \mathrm{~g}$ $\mathrm{KH}_{2} \mathrm{PO}_{4}, 1.15 \mathrm{~g} \mathrm{Na}_{2} \mathrm{HPO}_{4}$ in 1.0 litre $\mathrm{H}_{2} \mathrm{O}$ ) containing $0.1 \%$ gelatin (PBSG). The bacteria were resuspended in $\mathrm{M} 199$ (at $37^{\circ} \mathrm{C}$ ) to the desired cell density and $2 \mathrm{ml}$ of the bacterial suspension was added to wells containing tissue. This volume completely covered the tissue blocks. The tray was then incubated in a humidified $5 \%(\mathrm{v} / \mathrm{v})$ $\mathrm{CO}_{2}$ chamber at $36.5^{\circ} \mathrm{C}$, and tissue fragments were removed for study at the times specified. The tissue was removed aseptically, placed in a beaker, vigorously mixed in $25 \mathrm{ml}$ PBSG (to remove non-adherent bacteria), weighed and homogenized in $1.0 \mathrm{ml}$ PBSG with a $5 \mathrm{ml}$ Potter-Elvehjem tissue grinder. Serial dilutions of the homogenate were plated on GC agar plates and incubated overnight in $5 \%(\mathrm{v} / \mathrm{v}) \mathrm{CO}_{2}$ at $36.5{ }^{\circ} \mathrm{C}$, and the number of bacteria per tissue fragment was calculated. Each strain was tested five times with tissue fragments derived from different animals. Uninoculated tissue sections were homogenized, diluted and plated in duplicate; one set was incubated in an anaerobic chamber (Gas-Pak), the second in $5 \%(v / v) \mathrm{CO}_{2}$ in air, and both were incubated at $36.5^{\circ} \mathrm{C}$. This allowed determination of the number of indigenous bacteria adhering to, or present within, the tissue fragment. Indigenous flora was defined as those organisms which had a different colonial morphology than $H$. influenzae on agar plates, did not require NAD and haemin for growth and were not short or pleomorphic Gramnegative rods.

Antisera. Small donkeys (burros) were used for immunization; the protocol developed by Dr John Robbins (National Institutes of Health, Bethesda, Md., USA) was followed. This consisted of intravenous administration of an increasing dose of formalin-treated $\boldsymbol{H}$. influenzae three times a week for an eight week period. One animal was immunized with a formalin-treated type $b(\mathrm{Sb})$ strain $\mathrm{E}_{1}$ and another with a type $b$ strain no longer capable of producing detectable levels of capsule ( $\mathrm{Rb}$ ), Santo $\mathrm{Rb}$ (Roberts et al., 1981). Both strains used were unable to agglutinate human red blood cells and did not have pili when examined by electron microscopy. Postimmunization serum was collected, heated to $56^{\circ} \mathrm{C}$ for $30 \mathrm{~min}$ and stored at $-20^{\circ} \mathrm{C}$. Antibody titre directed against somatic antigens was determined by slide agglutination, while anticapsular titres were determined by the Ouchterlony diffusion technique using purified polyribophosphate (PRP; Anderson et al., 1971). Crude antisera similarly prepared have been shown to have activity against 21 Haemophilus antigens, including one against PRP (Buckmire, 1976). The Sb antiserum had a titre of 256 in agglutination tests and a titre of 16 in double diffusion tests. The $\mathbf{R b}$ antiserum had a titre of 512 in agglutination tests and no detectable titre against PRP. Preimmune sera did not have detectable titres by these methods. No measurable bactericidal activity was found with any of the heat-inactivated sera (Anderson et al., 1971); a complement source was not added.

Absorption of antisera. Santo $\mathrm{Rb}$ was grown in $250 \mathrm{ml} \mathrm{BHI}$ broth for $6 \mathrm{~h}$ and harvested by centrifugation at 5000 r.p.m. $(2400 \mathrm{~g})$ for $15 \mathrm{~min}$. The cells were resuspended in $20 \mathrm{ml}$ PBS containing $0.5 \%(\mathrm{v} / \mathrm{v})$ formalin and stored at $4{ }^{\circ} \mathrm{C}$ overnight; the cells were then washed twice as above and resuspended in $5 \mathrm{ml}$ PBS. Antiserum $(5 \mathrm{ml})$ raised against strain $\mathrm{Sb}$ was mixed with $2.5 \mathrm{ml}$ bacterial suspension, incubated at $37^{\circ} \mathrm{C}$ for $2 \mathrm{~h}$, and then stored overnight at $4^{\circ} \mathrm{C}$. The mixture was centrifuged at 5000 r.p.m. for $10 \mathrm{~min}$. The top layer was removed and 
recentrifuged. The resulting absorbed antiserum had a much lower agglutination titre (16) than the original untreated serum (256). In contrast. the anti-PRP titre was unaffected by the procedure and remained at 16 . Antiserum $(5 \mathrm{ml})$ raised against strain $\mathrm{Rb}$ was treated with Santo $\mathrm{Rb}$ bacteria. The absorbed antiserum had an agglutination titre of 32, which was also lower than that of the original untreated serum (512).

Polyribophosphate purification. PRP was prepared from strain $\mathrm{E}_{1}$ as previously described (Anderson et al., 1972, 1976).

Biotyping. This was done as previously described (Back \& Oberhofer, 1978) using the Minitek method (BBL, Beckton Dickinson \& Co., Cockeysville, Md., USA).

Chemical reagents. Sugars and human albumin were obtained from Sigma.

Histopathology. Selected tissue fragments were washed in $25 \mathrm{ml} \mathrm{PBSG}$, fixed in formaldehyde, embedded, sectioned and stained with haematoxylin and eosin for light microscopy. Other samples were washed and fixed in $6.25 \%(\mathrm{v} / \mathrm{v})$ glutaraldehyde in $0.1 \mathrm{M}$-cacodylate buffer, $\mathrm{pH} 7.3$. The specimens were post-fixed with $2 \%(\mathrm{v} / \mathrm{v})$ osmium tetroxide in sodium collidine, $\mathrm{pH} 7 \cdot 4$, dehydrated and embedded in Epon, and examined with an electron microscope (Zeiss model EM-9).

Statistical analysis. This was done using the F-test (Armitage, 1974).

\section{RESULTS}

Organ culture properties

Uninfected tissue was examined after various incubation times in M199 to assess cell damage and loss of cilia over a period of time. No detectable tissue changes were found in the first $36 \mathrm{~h}$ by microscopic and histologic examination. Incubation in M199 supplemented with penicillin $\mathrm{G}$ and streptomycin for 10-30 min caused no visible tissue damage; however, loss of cytoplasmic detail was observed after $24 \mathrm{~h}$ in this medium.

The presence of indigenous flora was determined. Infant animals (0-5 d old) had undetectable colonization ( $<10$ bacteria $\mathrm{ml}^{-1}$ ), while older animals of $(>5 \mathrm{~d}$ old $)$ had a small population (10100 bacteria $\mathrm{ml}^{-1}$ ) of facultative Gram-negative anaerobes and a few Gram-positive species. These did not appear to affect $H$. influenzae growth and were not a problem for the study.

\section{Conditions for adhesion}

Strains $\mathrm{E}_{1}$ and Santo $\mathrm{Rb}$ were chosen for the pilot experiments because they have been well characterized in in vivo models and have been shown to be capable of colonizing the infant rat and monkey after intranasal inoculation (Moxon \& Vaughn, 1981; Roberts et al., 1981; Scheifele et al., 1980).

Identical tissue fragments were incubated together in the same bacterial suspension, rinsed in $25 \mathrm{ml}$ PBSG once, twice or three times, and the colony counts compared with unrinsed tissue. After rinsing 1.2-1.9 $\times 10^{6}$ bacteria were recovered regardless of the number of rinses in PBSG. In contrast, the tissue incubated without rinsing had a consistently greater number of bacteria $\left(2 \cdot 1-4 \cdot 2 \times 10^{6}\right)$. Since one rinse of the tissue in PBSG appeared to remove non-adherent bacteria, and further rinsing had little effect on the number of organisms associated with the tissue fragments, we inferred that these residual bacteria were 'adherent'.

The effect of tissue size on the number of adhering bacteria was examined. Adult tissue was cut into different-sized blocks ( 10 to $220 \mathrm{mg}$ ) and incubated with $10^{8}$ c.f.u. of strain $E_{1}$ for $60 \mathrm{~min}$. The number of adherent bacteria per fragment increased from $0.3 \times 10^{6}$ to $1.6 \times 10^{6}$ as the tissue fragments increased from 30 to $220 \mathrm{mg}$. Fragments weighing $90 \mathrm{mg}$ were easy to manipulate and were selected for use in this study. On any one day the weight of the fragments varied by $<1.0 \mathrm{mg}$ while the ciliated surface areas remained the same; fragments prepared on different days varied by $<20 \mathrm{mg}$. The effect of the cut edge was examined by comparing blocks with similar weights and surface areas but having one, two or three cut edges. No significant differences in the number of adherent bacteria were observed. Electron microscopic examination revealed no bacteria adhering to the cut edges of the tissue fragments, while bacteria were seen to be associated with the cilia, suggesting that the bacteria preferentially bind to the ciliated surface. This correlates with observations in other studies (Denny, 1974).

The effect of inoculum size on the ability of strain $E_{1}$ to adhere to adult respiratory mucosa is illustrated in Fig. 1. With adult tissue, bacterial adherence increased linearly with bacterial 


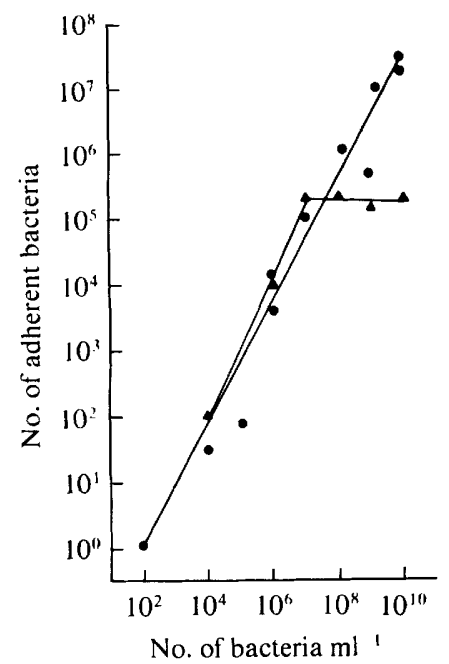

Fig. 1



Fig. 2

Fig. 1. Numbers of $H$. influenzae strain $\mathrm{E}_{1}$ adhering to adult tissue blocks at different bacterial concentrations. $\Delta$, Infant tissue; $\boldsymbol{O}$, adult tissue. The means of three experiments after $60 \mathrm{~min}$ incubation are shown.

Fig. 2. Adherence of $H$. influenzae strain $\mathrm{E}_{1}$ to adult nasal tissue with increasing incubation time Starting concentrations of $10^{10}(O), 10^{9}(\boldsymbol{\Lambda})$ and $10^{8}(\square)$ bacteria were used. The means of two experiments are shown.

concentration in the range $10^{2}-10^{10} \mathrm{ml}^{-1}$. In contrast, the binding capacity of the infant tissue appeared to be saturated at $10^{6}$ bacteria per fragment. Animals three weeks old, or older, had larger turbinates that could be cut into blocks 50-90 mg net weight with surface areas similar to adult fragments; these had more adherent bacteria. However, when large fragments from young animals ( 3 weeks to 6 months old) were examined they consistently had fewer adherent bacteria than adult tissue incubated in the same bacterial suspension.

The influence of incubation time on the adherence of bacteria to adult tissue was examined at three inocula $\left(10^{10}, 10^{9}\right.$ and $10^{8}$ c.f.u.). The majority of adherence occurred within the first 30 min (Fig. 2); similar results were found with infant tissue. Sections of tissue incubated with strains $\mathrm{E}_{1}$ or Santo $\mathrm{Sb}$ for $30 \mathrm{~min}$ were washed and prepared for electron microscopic examination. After 30 min incubation bacteria were associated primarily with cilia (Fig. 3). After incubation for $60 \mathrm{~min}$ bacteria were associated with cell surfaces, and internal vacuoles which appeared to contain bacteria were evident for $E_{1}$. Longer incubation periods ( $>90 \mathrm{~min}$ ) were required for Santo $R b$ to become internalized (Fig. 4). We found no significant differences in adherence patterns between early exponential phase organisms and organisms harvested in the early stationary stage (data not shown).

The reproducibility of results from different animals was examined by testing the adherence of $10^{8}$ c.f.u. of strain $E_{1}$ with tissue from six adult and six infant monkeys. One animal was examined per day and four or six tissue blocks were prepared from each animal and assayed. The adherence of $E_{1}$ for the six different animals, expressed as number of organisms per block, was calculated as $1.8 \pm 0.5(\mathrm{SD}) \times 10^{6}$ c.f.u. using adult tissue and $0.19 \pm 0.09(\mathrm{SD}) \times 10^{6}$ c.f.u. using infant tissue. Variation between different tissue blocks from the same animal was less than with tissue from different animals; SD $\pm 0.2 \times 10^{6}$ with the same adult animal and SD $\pm 0.5 \times 10^{6}$ between different adult animals.

Bacteria were incubated in M199 with $10 \%$ foetal calf serum and in M199 without serum, to rule out the possibility of bacterial adherence to foetal calf serum components. No difference was observed with either $\mathrm{Sb}$ or $\mathrm{Rb}$ cells when the test was done without serum in the media. 


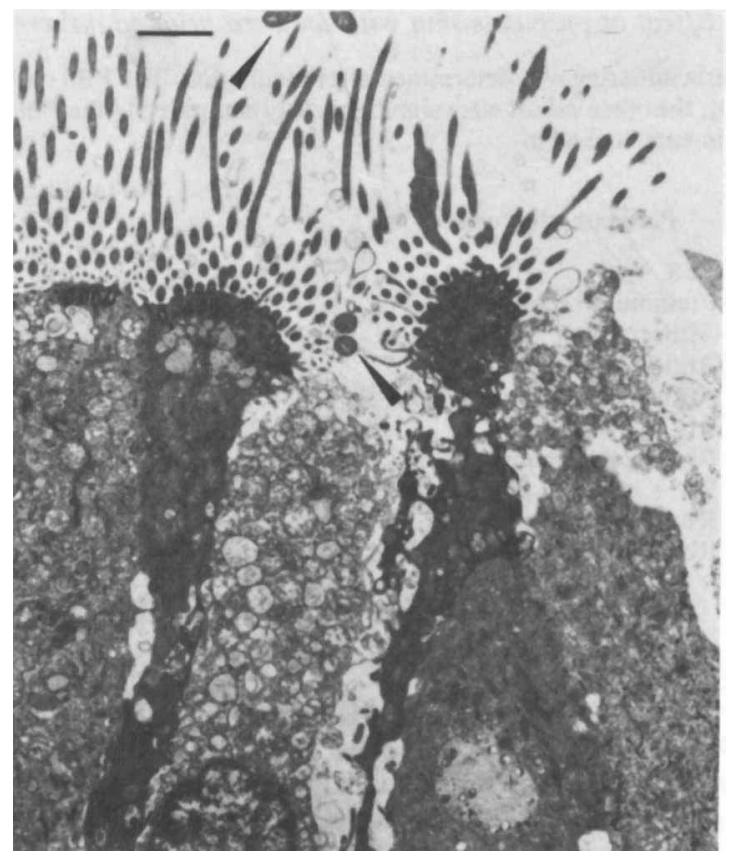

Fig. 3. Electron micrograph of nasal tissue after $30 \mathrm{~min}$ incubation with strain $E_{1}$. The arrows indicate bacterial forms in association with cilia. Bar, $2 \mu \mathrm{m}$.

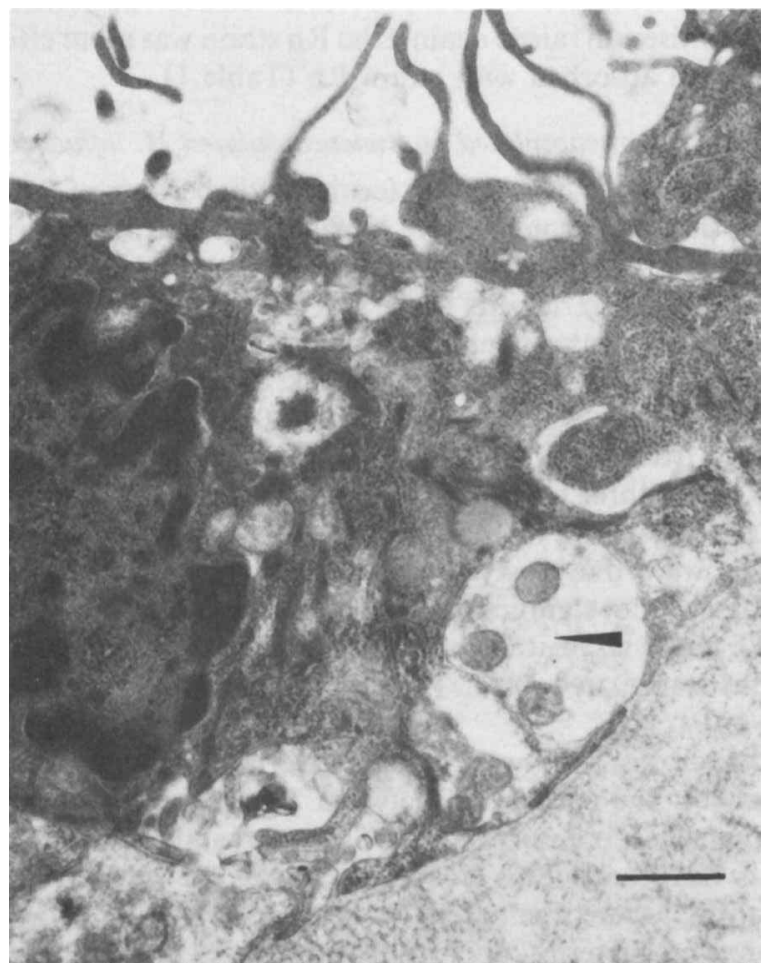

Fig. 4. Electron micrograph of tissue incubated with Santo $\mathrm{Rb}$ for $180 \mathrm{~min}$. Internalized cells are indicated by the arrow. Bar, $1 \mu \mathrm{m}$. 
Table 1. Effect of preincubation with antisera prior to adherence testing The number of bacteria adhering was determined after incubation. The PBS control values ( $10^{6} \mathrm{c.f.u}$.)
were defined as $100 \%$; the other values were simultaneously compared to the PBS control. The mean of
four different experiments is shown.

Preincubation conditions

$\mathrm{E}_{1}+$ PBS

$\mathrm{E}_{1}+$ Preimmune sera

$\mathrm{E}_{1}+$ Antisera $\mathrm{Sb}$

$\mathbf{E}_{1}+$ Antisera $\mathbf{R b}$

$\mathrm{E}_{1}+$ Antisera $\mathrm{Sb}$, absorbed with $\mathrm{Rb}$

Santo Rb + PBS

Santo $R b$ + preimmune sera

Santo $\mathbf{R b}+$ antisera $\mathrm{Sb}$

Santo $R b+$ antisera $R b$

Santo $\mathbf{R b}$ + antisera $\mathbf{R b}$, absorbed with $\mathbf{R b}$
Adherent bacteria

$(\%)$

100

90

33

14

67

100

95

30

10

95

\section{Inhibition of adherence}

D-Glucose, D-mannose, D-galactose, ribitol, L-rhamnose, D-raffinose, D-arabinose, D-fructose, D-fucose, D-xylose, D-ribose, sucrose or human albumin, all at $500 \mu \mathrm{g} \mathrm{m}^{-1}$, or PRP at $200 \mu \mathrm{g} \mathrm{ml}^{-1}$ were incubated with either strain $\mathrm{Rb}$ or Sb at $36.5^{\circ} \mathrm{C}$ for $30 \mathrm{~min}$ prior to exposure to tissue. None of the 12 sugars tested blocked adherence, and neither albumin nor PRP altered the ability of bacteria to adhere. Antisera at a 1/75 dilution in M199 were incubated with selected bacterial strains for $60 \mathrm{~min}$ at $36.5^{\circ} \mathrm{C}$. At this dilution, clumping of the cells was not visually apparent, and the number of c.f.u. was not reduced in comparison to bacteria incubated without antisera. This concentration of antisera was added to the bacteria prior to incubation with the tissue. Preimmune sera had little effect on adherence; in contrast, antisera reduced the ability of the bacteria to adhere. Antiserum raised against the Rb strain was more effective than either the $\mathrm{Sb}$ antiserum or antiserum absorbed with strain $\mathrm{Rb}$ (Table 1).

\section{Adherence of capsulated and unencapsulated $H$. influenzae}

Nasal tissue from adult animals was chosen for the study because of the ready availability of these tissue specimens. Tissue fragments were inoculated with $10^{8}$ bacteria and incubated for $60 \mathrm{~min}$ at $36.5^{\circ} \mathrm{C}$ to examine the ability of selected capsulated and unencapsulated $H$. influenzae strains to adhere (Table 2). The variability in the size of the inoculum between experiments was $<5.0 \times 10^{5}$ c.f.u. Twenty strains (six-unencapsulated, nine type $\mathrm{b}$ and five of other capsule types) adhered at $<2.0 \times 10^{6}$ bacteria per tissue block. Nine strains (four unencapsulated, one type $b$ and four of other capsule types) adhered at $>2.0 \times 10^{6}$ bacteria per tissue block. The adherence values ranged from $0.3 \times 10^{6}$ to $11.4 \times 10^{6}$ bacteria per tissue block. DC33, DC15 (type b), GL-14 (type e), the three type f strains and C500 and C501 (unencapsulated) were the least adherent strains $\left(<1.0 \times 10^{6}\right)$ while C668 (type b), C188 (type c) and C546, GL-8 and C800 (unencapsulated) were the most adherent $\left(>5.0 \times 10^{6}\right)$. However, as a group, the unencapsulated strains were not significantly more adherent $(P>0 \cdot 1)$ than either the type b or types a, c, d, e or $\mathrm{f}$. We found no relationship between adherence and site of strain isolation for either capsulated or unencapsulated strains (Fig. $5 a$ ). There was no correlation between biotype and adherence (Fig. $5 b$ ).

The use of isogenic strains eliminates other bacterial characteristics which could effect adherence. To further test the correlation between adherence capacity and the presence of capsule, two unencapsulated laboratory strains, Santo Rb and Good Rd, and their capsulated transformants (Santo Sa, Santo Sb, Good Sa, Good Sb, Good Sd), and $\mathrm{E}_{1}$ and the unencapsulated mutant $S_{2}$, were compared (Roberts et al., 1981). No significant difference $(P>0 \cdot 1)$ in the number of bacteria adhering to a fragment was observed between isogenic capsulated and unencapsulated derivatives. Piliated and non-piliated isogenic pairs of $E_{1}$ also showed no significant differences in in vitro adherence. 
Table 2. Adherence of Haemophilus influenzae to nasal turbinates in culture

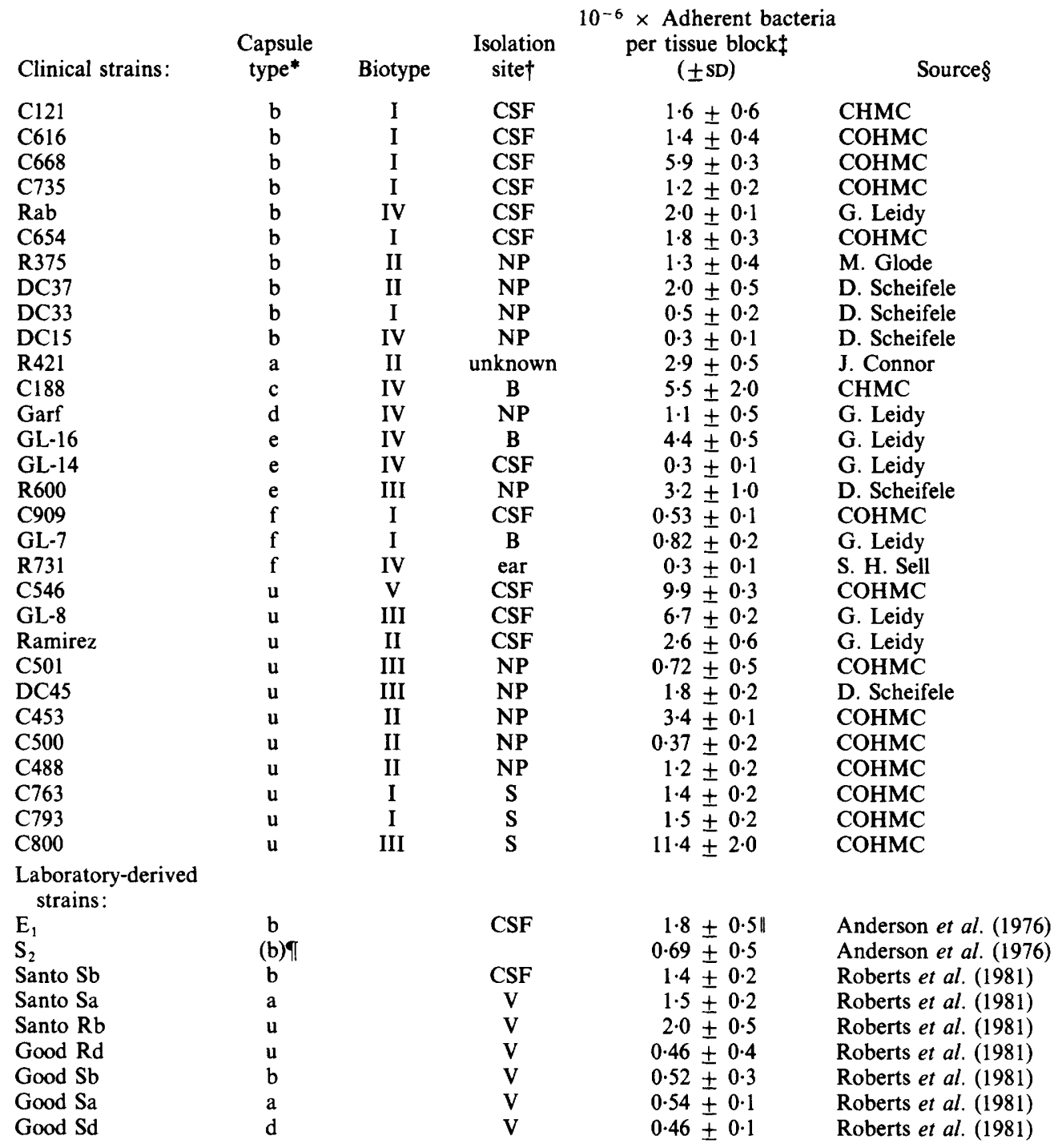

* Typed by using Difco antisera for types a-f; $u$ indicates unreactive with this antiserum.

$\dagger$ CSF, cerebrospinal fluid; B, blood; NP, nasopharynx; S, sputum; V, variant.

$\$$ Means of five separate experiments.

§ COHMC, Children's Orthopedic Hospital and Medical Center, Seattle, Wash., USA; CHMC, Children's Hospital and Medical Center, Boston, Mass., USA; G. Leidy, Columbia University College of Physicians and Surgeons, New York, NY, USA; M. Glode, Children's Hospital, Denver, Colo., USA; D. Scheifele, Children's Hospital, Vancouver, BC, Canada; J. Connor, University of California, San Diego, Calif., USA; S. H. Sell, Vanderbilt University, Nashville, Tenn., USA.

$\|$ Mean of six separate experiments.

If Produces $<1 / 1000$ the amount of capsule compared to the parent $\mathrm{E}_{1}$.

\section{Penetration of nasal tissue in culture}

Initial experiments with strain $\mathrm{E}_{1}$ and Santo $\mathrm{Rb}$ indicated that $H$. influenzae could penetrate the epithelial layer of the tissue fragment. Isogenic strains $E_{1}, S_{2}$, Santo $S b$, Santo Sa and Santo $\mathrm{Rb}$ were chosen for further study. No difference in penetration capacity was found when capsulated organisms were compared with unencapsulated isogenic derivatives. However, 

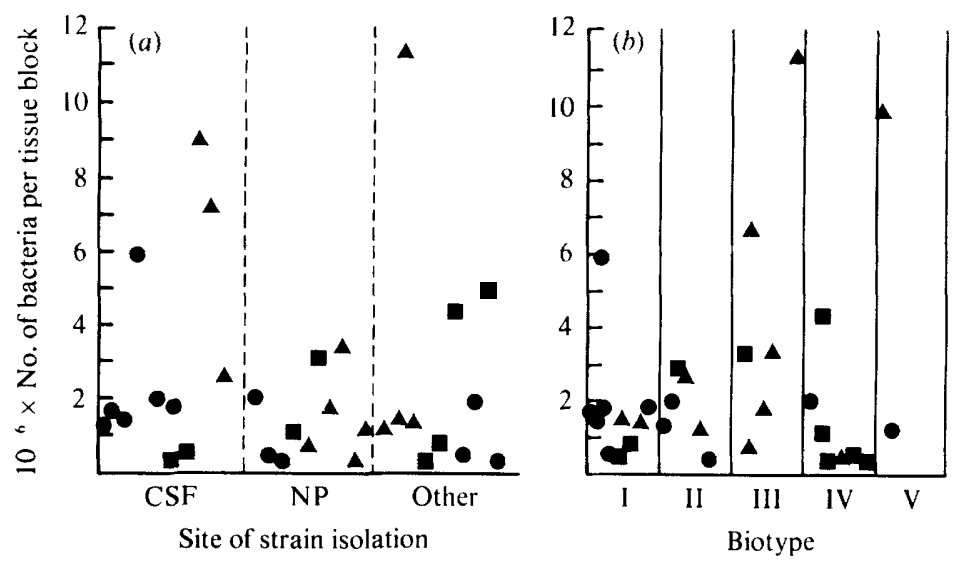

Fig. 5. In vitro adherence (see Table 2) is plotted versus source of isolation (a) or biotype (b). $\mathbf{\bullet}, H$. influenzae type b; $\boldsymbol{\square}$, types a, c, d, e, f; $\boldsymbol{\Lambda}$, unencapsulated strains. CSF, cerebrospinal fluid; NP, nasopharynx; Other, blood or sputum isolation site.

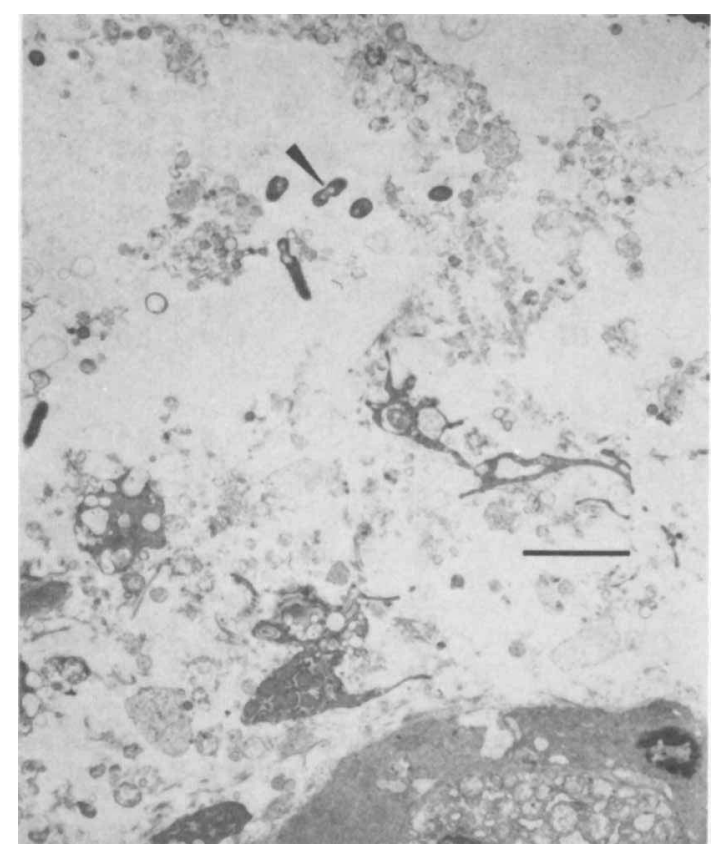

Fig. 6. Electron micrograph of tissue containing bacteria dividing in the submucosa (arrowed). Bar, $2 \mu \mathrm{m}$.

strain-to-strain variation in the time required for penetration as assayed by electron microscopic examination was evident. Both $E_{1}$ and its unencapsulated derivative $S_{2}$ penetrated the tissue in a short (30-60 $\mathrm{min}$ ) incubation period. Structures which appeared to be bacteria enclosed within vacuoles near the cell surfaces were found in tissue samples after $30 \mathrm{~min}$ and $60 \mathrm{~min}$ incubation. After $60 \mathrm{~min}$ bacteria were found in the submucosa some distance from the cell surface. Occasionally organisms in these locations were seen to be dividing (Fig. 6). In contrast, the Santo derivatives required longer incubation times $(3-4 \mathrm{~h})$ before penetration was observed. 


\section{DISCUSSION}

Two groups have examined the in vitro adherence of $H$. influenzae (Lewis \& Dajani, 1980; Lampe et al., 1982). Both found capsulated type b strains to adhere poorly to buccal epithelial cells or established cell lines, while unrelated unencapsulated strains had increased adherence capacity. However, unencapsulated $H$. influenzae, like Gram-negative enteric bacteria, did not adhere in large numbers to buccal epithelial cells (Lampe et al., 1982). They suggested that differential adherence between capsulated and unencapsulated strains could explain differences in colonization, pathogenesis and types of infection caused by these strains. Our findings differ from their results. Less adherent strains were identified in both capsulated and unencapsulated groups. However, we found no correlation between capsulation and the ability of bacteria to adhere to organ cultures. Nor could adherence be correlated with biotype or original anatomic site of isolation.

Recent studies have demonstrated that the attachment of Neisseria meningitidis to pharyngeal cells was better than their attachment to buccal epithelial cells (Craven et al., 1980; Salit \& Morton, 1981). This suggests that the cells present in the tissue normally colonized by the organism under study should be used for adherence studies. Neither buccal epithelial cells nor established cell lines resemble the ciliated nasopharyngeal tissue usually colonized by $H$. influenzae, and experiments with such cells may not accurately represent the in vivo environment. For this reason we used nasal mucosa for adherence assays. Inherent differences in the cells used could greatly influence the apparent adherence patterns of $H$. influenzae. Nasopharyngeal tissue derived from subhuman primates may bind $H$. influenzae differently than human buccal epithelial cells; this also could explain the differences between our results and those obtained by Lampe et al. (1982).

Guerina et al. (1982) found that non-piliated and poorly piliated $H$. influenzae adhered in lower numbers to human oropharyngeal cells as compared to moderate-to-heavily piliated bacteria. Our initial findings suggested that the presence of pili did not greatly influence adherence; however, we did not determine the grade of piliation of the bacteria. Therefore, piliation can not be ruled out as a potential bacterial adhesin.

With similarly-sized tissue fragments adherence to adult monkey tissue was greater than to tissue from infants. Therefore, it is possible that the number and distribution of tissue receptors for $H$. influenzae changes with age.

Adherence was neither inhibited nor enhanced by the 12 sugars tested or by albumin or foetal calf serum. This correlates with observations by Wideback \& Kronvall (1982) who found that the four strains of $H$. influenzae they examined did not adhere to albumin. Antiserum directed against noncapsular antigens ( $\mathbf{R b}$ antiserum) inhibited adherence better than either $\mathbf{S b}$ antiserum or antiserum to strain $\mathrm{Sb}$ absorbed with strain $\mathrm{Rb}$. This suggests that the bacterial adhesin(s) of $H$. influenzae are more likely to be surface molecules other than capsule.

When compared with other type $\mathrm{b} H$. influenzae, strain $\mathrm{E}_{1}$ is more virulent in animals (Roberts et al., 1981 and unpublished observations). Similarly, our preliminary data suggest that strain $\mathrm{E}_{1}$ and its unencapsulated derivatives are able to penetrate the organ culture faster (30 to $60 \mathrm{~min}$ ) than other strains tested $(>90 \mathrm{~min})$. Therefore, it is possible that the adherence assay underestimates the number of adherent bacteria or that the value represents both internal and external bacteria for this strain.

The stability of bacterial binding was examined by removing the bacterial suspension and replacing it with fresh M199. The loss of adherent bacteria was not significant, suggesting that bacteria-tissue interaction is more complex than the steady state between binding and release of bacteria. The possibility that there is more than one adhesin-receptor interaction has been suggested in other systems (Gibbons $e t$ al., 1983) and must be considered with $H$. influenzae.

The tissue used in these studies was colonized by a small population of indigenous bacteria, which could have decreased or enhanced adherence of $H$. influenzae. The actual number of bacteria in this system was less than that found on buccal or pharyngeal cells used in other adherence studies (Gibbons \& Van Houte, 1971; Salit \& Morton, 1981). Normal flora organisms were not seen in cultures containing isolated colonies of $H$. influenzae, presumably because of the 
low numbers, but the use of a non-sterile system more closely resembles the normal in vivo conditions for $H$. influenzae colonization.

Previous data obtained in vivo from rats indicated that submucosal colonies of $H$. influenzae are evident $48 \mathrm{~h}$ after inoculation in nasal turbinates (Smith et al., 1982). The penetration studies reported here suggest that the presence or absence of the capsule does not appear to influence the ability of the organism to penetrate the tissue in culture. It is possible that the differences in the time required for penetration may play a role in virulence.

The data presented here suggest that, as a group, unencapsulated $H$. influenzae are not more adherent than capsulated strains. Our data also suggest that the distribution of $H$. influenzae in the human population may not be attributed solely to the presence or absence of a capsule as suggested by Lampe et al. (1982).

Organ models have been used successfully to study and gain information about other bacteria (Gabridge et al., 1978; McGee et al., 1976; Ramphal \& Pyle, 1983). The model described here should contribute to the study of adherence and its relationship to colonization and disease. Such work may lead to better ways of controlling, treating, and preventing Haemophilus disease.

This work was supported by grant AI18186 from the National Institute of Allergy and Infectious Diseases. M. R. was supported by New Investigator Award AI17761 from the National Institute of Allergy and Infectious Diseases. Primate tissue specimens were obtained from the Regional Primate Research Center at the University of Washington which is supported by NIH grant RR00166. We wish to thank W. Cameron, J. Johnsen and A. Yasutake for their technical assistance.

\section{REFERENCES}

Anderson, P., Johnston, R. B. \& SMith, D. H. (1971). Human serum activities against $H$. influenzae type $b$. Journal of Clinical Investigation 52, 31-38.

ANDERSON, P., Johnston, R. B., JR, Wetterlow, L. H. \& SMITH, D. (1972). Immunization of humans with polyribophosphate, the capsular antigen of Haemophilus influenzae, type b. Journal of Clinical Investigation 51, 39-44.

Anderson, P., PItT, J. \& SMITH, D. H. (1976). Synthesis and release of polyribophosphate by Haemophilus influenzae type $\mathrm{b}$ in vitro. Infection and Immunity 13, 581-589.

ARMitage, P. (1974). Statistical Methods in Medical Research, pp. 131-138. New York: John Wiley and Sons.

BACK, A. E. \& Oberhofer, T. R. (1978). Use of the minitek system for biotyping Haemophilus species. Journal of Clinical Microbiology 7, 312-313.

BEACHEY, E. H. (1981). Bacterial adherence: adhesinreceptor interactions mediating the attachment of bacteria to mucosal surfaces. Journal of Infectious Diseases 143, 325-345.

BUCKMIRE, F. L. A. (1976). Identification and quantification of capsular antigen in capsulated and noncapsulated strains of $H$. influenzae type b by crossedimmunoelectrophoresis. Infection and Immunity 13, 1733-1742.

Craven, D. E., Peppler, M. S., Frasch, C. E., Mocca, L. F., McGrath, P. O. \& Washington, G. (1980). Adherence of isolates of Neisseria meningitidis from patients and carriers to human buccal epithelial cells. Journal of Infectious Diseases 142 , 556-568.

DENNY, F. W. (1974). Effect of a toxin produced by Haemophilus influenzae on ciliated respiratory epithelium. Journal of Infectious Diseases 129, 93-100.

Gabridge, M. G., Gunderson, H., SchaEFFer, S. L. \& BURDEN-STAHL, Y. D. (1978). Ciliated respiratory epithelial monolayers: new model for Mycoplasma pneumoniae infection. Infection and Immunity 21, 333-336.

GibBons, R. S. \& VAN HouTE, J. (1971). Selective bacterial adherence to oral epithelial surfaces and its role as an ecological determinant. Infection and Immunity 3, 567-573.

Gibbons, R. S., Moreno, E. C. \& ETHERden, I. (1983). Concentration-dependent multiple binding sites on saliva-treated hydroxyapatite for Streptococcus sanguis. Infection and Immunity 39, 280-289.

Guerina, N. G., langerman, S., Clegg, H. W., Kessler, T. W., Goldman, D. A. \& GilsdoRF, J. R. (1982). Adherence of piliated Haemophilus influenzae type $b$ to human oropharyngeal cells. Journal of Infectious Diseases 146, 564.

GUYOT, G. (1908). Uber die bakterielle Hamagglutination. Zentralblatt für Bakteriologie 47, 604-653.

Johanson, W. G., JR, Woods, D. E. \& Chaudhari, T. (1979). Association of respiratory tract colonization with adherence of Gram-negative bacilli to epithelial cells. Journal of Infectious Diseases 139, 667-673.

LaMPe, R. M., Mason, E. O., KaPlan, S. L., Umstead, C. L., Yow, M. D. \& FEIGIN, R. D. (1982). Adherence of Haemophilus influenzae to buccal epithelial cells. Infection and Immunity 35, 166-172.

LEWIS, J. M. \& DAJANI, A. S. (1980). Adherence of Haemophilus influenzae to human epithelial cells. In Abstracts of the Annual Meeting of the American Society for Microbiology, p. 26. Washington, DC: American Society for Microbiology.

MCGeE, Z. A., Johnson, A. P. \& TAYLOR-RoBinson, D. (1976). Human fallopian tubes in organ culture: preparation, maintenance, and quantitation of damage by pathogenic microorganisms. Infection and Immunity 13, 608-618.

MCGee, Z. A., Johnson, A. P. \& TAYLOR-Robinson, D. (1981). Pathogenic mechanisms of Neisseria 
gonorrhoeae: observations on damage to human fallopian tubes in organ culture by gonococci of colony type 1 or type 4. Journal of Infectious Diseases 143, 413-422.

Moxon, E. R. \& Vaughn, K. A. (1981). The type b capsular polysaccharide as a virulence determinant of Haemophilus influenzae: studies using clinical isolates and laboratory transformants. Journal of Infectious Diseases 143, 517-524.

RAmphal, R. \& Pyle, M. (1983). Adherence of mucoid and non-mucoid Pseudomonas aeruginosa to acidinjured tracheal epithelium. Infection and Immunity 41, 345-351.

ReEd, W. P. \& Williams, R. C., JR. (1978). Bacterial adherence: first step on pathogenesis of certain infections. Journal of Chronic Diseases 31, 67-72.

Roberts, M., Stull, T. L. \& SMTth, A. L. (1981). Comparative virulence of Haemophilus influenzae with $\mathrm{a}$ type $\mathrm{b}$ or type $\mathrm{d}$ capsule. Infection and Immunity 32, 518-524.
Salit, I. E. \& Morton, G. (1981). Adherence of Neisseria meningitidis to human epithelial cells. Infection and Immunity 31, 430-435.

SCHEIFELE, D. W., DAWN, R. S., SYRiopoulou, V. P., AVERILL, D. R. \& SMITH, A. L. (1980). Haemophilus influenzae, bacteria and meningitis in infant primates. Journal of Laboratory and Clinical Medicine 95, $450-462$.

Smith, A. L., Daum, R. S., Scheifele, D., SyriopoLOU, V., AVerill, D. R., Roberts, M. C. \& STULl, T. L. (1982). Pathogenesis of Haemophilus influenzae meningitis. In Haemophilus influenzae: Epidemiology, Immunology and Prevention of Disease, pp. 89109. Edited by S. H. Sell \& P. F. Wright. Amsterdam: Elsevier Science Publishing.

Wideback, K. \& Kronvall, G. (1982). Surface receptors for serum albumin in group $C$ and $G$ Streptococci show three different types of albumin specificity. Infection and Immunity 38, 1154-1163. 